\title{
Morphological sexual maturity by relative growth technique of Uca maracoani (Brachyura, Ocypodidae) from a tropical mangrove
}

Despite of the existence of previous knowledge on the relative growth of $U$. maracoani for a population of southeastern Brazilian coast, the aim of the study was described and compare the relative growth patterns and sexual maturity of this species from Formoso River mangrove, state of Pernambuco, northeast Brazil, with data from other locations and of congeneric species. The crabs were monthly sampled manually, with a capture effort by one person colleting for 30 minutes at the low tide from April 2009 to March 2010 . Crabs of both sexes were measured with a caliper at following dimensions: carapace width (CW), carapace length (CL), cheliped propodus length (CPL), cheliped propodus height (CPH) and abdomen width (AW). Additionally, males were also measured at their gonopod length (GL). The determination of morphological maturity was based on the relationship between the CPL vs. CW for males and $A W$ vs. CW for females, which were the relations that best evidenced the beginning of the morphological sexual maturity for $U$. maracoani. The relationships CPL vs. CW and AW vs. CW evidenced positive allometry for juveniles and adult's males and females. However, a negative allometry was observed in the relationship CL vs. CW and GL vs. CW for juveniles and adult's males, AW vs. CW for adults' males and, CPH vs. CW for adults' females. The growth pattern shown by the female abdomen probably is related to egg incubation and the excessive growth observed at the male cheliped is probably related to reproductive process, because this appendage is used at the courtship and intra or inter specific agonistic interactions with other males. The morphological sexual maturity of males was estimated at $15.8 \mathrm{~mm} \mathrm{CW}(50 \%$ of males), with the smallest mature male measuring $17.34 \mathrm{~mm}$, and the largest immature male $18.15 \mathrm{~mm} \mathrm{CW}$. Females reached morphological sexual maturity (50\%) at $13.8 \mathrm{~mm} \mathrm{CW}$, with the smallest mature female at $15.43 \mathrm{~mm}$ CW and the largest immature female at $16.32 \mathrm{~mm}$ CW. The differential growth patterns between juvile and adult phas, as well as the onset sexual maturity seem to have relationship with ontogenetic changes, which is mainly related to behavioral or reproductive traits. The growth pattern observed in the female's abdomen is probably related to hatching eggs while overgrowth shown in male cheliped should be related to reproductive processes, as this appendix is used in court and in specific interactions with other males.

Keywords: Morphometric relationships, Fiddler crabs, Reproduction biology, Crabs

\section{Maturidade sexual morfológica pela técnica de crescimento relativo de Uca maracoani (Brachyura, Ocypodidae) de um manguezal tropical}

Apesar dos conhecimentos prévios sobre o crescimento relativo de U. maracoani para uma população do litoral do Sudeste brasileiro, o objetivo do estudo foi descrever e comparar os padrões relativos de crescimento e da maturidade sexual desta espécie do manguezal do Rio Formoso, Estado de Pernambuco, Nordeste do Brasil, com dados de outras localidades e de espécies congenéricas. Os caranguejos foram amostrados manualmente, com um esforço de captura de 30 minutos na maré baixa de abril de 2009 a março de 2010 . Os caranguejos de amos os sexos form medios com um paquimetro nas seguintes dimensões: largura de carapaça (LC) comprimento da carapaca (CC), comprimento do própodo do quelípodo (CPQ), ( morfológica baseou-se na relação entre CPQ vs. LC para os machos e LA vs. LC para as fêmeas, que foram as relações que melhor evidenciaram o início da maturidade sexual morfológica para U. maracoani. As relações CPQ vs. LC e LA vs. LC evidenciaram alometria positiva para jovens e adultos masculinos e femininos. No entanto, observou-se uma alometria negativa $\mathrm{n}$ relação CC vs. LC e CG vs. LC para jovens e adultos masculinos, LA vs. LC para machos adultos e, APQ vs. LC para fêmeas adultas. O padrão de crescimento do abdômen feminin provavelmente está relacionado à incubação de ovos e o crescimento excessivo do quelípodo masculino provavelmente está relacionado ao processo reprodutivo, pois este apêndice é usado na corte e interações agonísticas com outros machos. A maturidade sexual morfológica dos machos foi estimada em 15,8 mm LC (50\%), com o menor macho maduro medindo 17,34 $\mathrm{mm} \mathrm{LC}$, e o maior macho imaturo, $18,15 \mathrm{~mm} \mathrm{LC}$. As fêmeas atingiram a maturidade sexual morfológica (50\%) a 13,8 mm LC, com a menor fêmea madura em 15,43 mm LC e a maior fêmea imatura em 16,32 $\mathrm{mm}$ LC. Os padrões diferenciais de crescimento entre fases juvis e adultas, bem como o início da maturidade sexual parecem ter relação com mudanças ontogenéticas, ovos, enquanto o crescimento excessivo mostrado no quelípodo masculino deve estar relacionado a processos reprodutivos, uma vez que este apêndice é usado na corte e em interaç̃̃es específicas com outros machos.

Palavras-Chave: Relações morfométricas; Caranguejos Violinista; Biologia da reprodução; Caranguejos.

Cibele Leandro da Costa

Universidade Federal de Pernambuco, Brasil

http://lattes.cnpq.br/2004147699907057

http://orcid.org/0000-0003-3446-5300

cibeleandro@gmail.com

\section{Sheila Maria da Silva Alves}

Universidade Federal do Agreste Meridional, Brasil

http://lattes.cnpq.br/6877548069713289

sheila-msa@hotmail.com

Cristiano Aparecido Chagas

Universidade Federal de Pernambuco, Brasil

http://lattes.cnpq.br/3655967111364115

chagas.cris@gmail.com

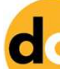

DOI: 10.6008/CBPC2179-6858.2021.005.0020
Marina de Sá Leitão Câmara de Araújo

Universidade de Pernambuco, Brasil

http://lattes.cnpq.br/4315354380176563

marina.araujo@upe.br

Daniela da Silva Castiglioni

Universidade Federal de Santa Maria, Brasil

http://lattes.cnpq.br/3218564740770442

danielacastiglioni@yahoo.com.br
Referencing this:

COSTA, C. L.; ALVES, S. M. S.; CHAGAS, C. A.; ARAÚJO, M. S. L. C.; CASTIGLIONI, D. S.. Morphological sexual maturity by relative growth technique of Uca maracoani (Brachyura, Ocypodidae) from a tropica mangrove. Revista Ibero Americana de Ciências Ambientais, v.12, n.5, p.221-231, 2021. DOI: http://doi.org/10.6008/CBPC21796858.2021 .005 .0020 


\section{INTRODUCTION}

According to Hartnoll (1982), the relative growth is defined by means of the growth of different body parts in relation to a body dimension that expresses the animal size as a whole. In Crustacea Brachyura the most evident growth changes appear in the cheliped, abdomen, and pleopods of both sexes, during the transition from juvenile to adult stages (HARTNOLL, 1985). The individual variation in the standard growth of some organs or body dimensions, between individuals of each sex in the same species or in different species, has a biological significance (HARTNOLL, 1978), and are important attributes in crustaceans for a better comprehension of population and reproductive biology. The relative growth patterns are also indicative of sexual dimorphism, and it can be used for developmental phase's prediction in crabs (BENETTI et al., 2004; HIROSE et al., 2007). The relative growth is used to estimate the size at puberty (PINHEIRO et al., 1998; FLORES et al., 2002; NEGREIROS-FRANSOZO et al., 2003; COLPO et al., 2004; DALABONA et al., 2005; GREGATI et al., 2007; HIROSE et al., 2007; CASTIGLIONI et al., 2011; ARAÚJO et al., 2011), to identify brachyuran species (RODRIGUES, 1976; HUBER, 1985), and to compare intraspecific variations among populations from different locations (BENETTI et al., 2004; CARDOSO et al., 2004; CASTIGLIONI et al., 2004; GARCÍA-DÁVILA et al., 2005; IBÁNEZ-AGUIRRE et al., 2006; HIROSE et al., 2012; HIROSE et al., 2012).

These more recent studies confirm predictions from other authors that variations in the size of sexual maturation may occur due to: abiotic factors acting locally, such as temperature and temperaturephotoperiod interaction; seasonality; latitudinal variations and geographic distribution of the populations (GIESE, 1959; WENNER et al., 1974; JONES et al., 1983; BURGGREN et al., 1988; ARAÚJO, 2007), since these factors influence the growth rates of these animals. Variations in sexual maturity size for the same species may occur at different spatial scales (DIAZ et al., 1989; HINES, 1982), even in nearby localities (ARAÚJO et al., 2012).

In the last decades, the relative growth in fiddler crabs have been extensively investigated (FRITH et al., 1983; COLBY et al., 1984; VON HAGEN, 1987; MASUNARI et al., 2003; CASTIGLIONI et al., 2004; BENETTI et al., 2004; MASUNARI et al., 2005; MASUNARI et al., 2005; HIROSE et al., 2007; COSTA et al., 2008; PRALON et al., 2008; ARAÚJO et al., 2012). In addition, intraspecific comparative studies have been performed (BENETTI et al., 2004; CARDOSO et Al., 2004; CASTIGLIONI et al., 2004; GARCÍA-DÁVILA et al., 2005; IBÁNEZ-AGUIRRE et al., 2006; CASTIGLIONI et al., 2011; HIROSE et al., 2012), and these authors found differences in the growth pattern among populations from different locations, which were attributed to environmental conditions.

Among the crabs of the Ocypodidae Family, are fiddler crabs, which were represented by 104 species, all belonging to the genus Uca (ROSENBERG, 2001). However, from the phylogenetic analyzes performed by Shih et al. (2016), the species of fiddler crabs were relocated in 11 genera, of which only three (Leptuca, Minuca and Uca) have species found in Brazil. In the Northeast of Brazil, there are nine species of fiddler crabs: Uca maracoani (LATREILLE, 1802-1803), Minuca vocator (HERBST, 1804), M. mordax (SMITH, 1870), M. rapax (SMITH, 1870), M. burgersi (HOLTHURIS, 1962), M. victoriana (VON 
HAGEN, 1987), Leptuca leptodactyla (RATHBUN, 1898), L. thayeri (RATHBUN, 1900) and L. cumulanta (CRANE, 1943) (MELO, 1996; CASTIGLIONI et al., 2010; THURMAN et al., 2013). The fiddler crab U. maracoani is distributed through the Western Atlantic, the Antilles, Venezuela, and Guyana, and along nearly the entire coast of Brazil, from the state of Maranhão to state of Paraná (MELO, 1996). This species lives near the mouths of rivers always at maximum ebb tide, in open mudflats without mangrove tress, in very soft silt, sandy silt or mud with a high content of organic matter, and in meso or euryhaline salinities (ALMEIDA et al., 2006; BEZERRA et al., 2006; THURMAN et al., 2013). Studies on the population dynamics of U. maracoani have been carried out in populations inhabiting the southern and south-eastern coast of Brazil (MASUNARI et al., 2005; KOCH et al., 2005; HIROSE et al., 2007, 2008; DI-BENEDETTO et al., 2009). In the northeast coast of Brazil, Bezerra et al. (2006) carried out a study on spatial distribution not only of $U$. maracoani, but also three other species of fiddler crabs from the state of Ceará. In addition, Silva et al. (2016) analyzed the population biology and size at sexual maturity of U. maracoani in a semi-arid tropical estuary of northeastern Brazil. Azevedo et al. (2017) analyzed the population dynamics of U. maracoani from a tropical mangrove located at the state of Pernambuco. Despite of the existence of previous knowledge on the relative growth of $U$. maracoani for a population of southeastern Brazilian coast, the aim of the study was described and compare the relative growth patterns of this species from Formoso River mangrove, state of Pernambuco, northeast Brazil, with data from other locations and of congeneric species.

\section{METHODOLOGY}

Specimens of Uca maracoani were collected in the Formoso River mangrove $\left(8^{\circ} 41^{\prime} 00.68\right.$ "S and $35^{\circ} 06^{\prime} 09.49^{\prime \prime}$ W), south coast of the state of Pernambuco, northeast Brazil. The fiddler crabs were collected monthly from April 2009 to March 2010 and removed from their burrows manually during low tide with a capture effort of 30 minutes by one collector. These burrows were excavated on the muddy substrate, reaching $1 \mathrm{~m}$ deep, thus requiring the collector to enter his/her arm completely to remove crabs. After collecting fiddler crabs, they were bagged, labeled, transported to laboratory and preserved in $70 \%$ ethanol until further analysis.

Crabs of both sexes were measured with a calliper at following dimensions: carapace width (CW), carapace length $(\mathrm{CL})$, cheliped propodus length $(\mathrm{CPL})$, cheliped propodus height $(\mathrm{CPH})$ and abdomen width (AW). Additionally, males were also measured at their gonopod length (GL). A principal component analysis (PCA) was carried out with the above variables, allowing us to distinguish groups of males and females that would represent juveniles and adults. Next, males and females were classified to each group using a Kmeans non-hierarchical clustering analysis. This technique is based on the establishment of predetermined groups (juveniles and adults), assigning the crabs to one of the groups according to their loads on the two axes of the PCA, by means an iterative process that minimizes the variance within groups and maximizes the variance between groups. Using the results of this classification (K-means), a further bivariate discriminant analysis can be applied allowing a reclassification of these groups by separating the crabs into juveniles (immatures) and adults (matures). This statistical procedure was based on Sampedro et al. (1999) 
and Corgos et al. (2006), which used a similar technique. Afterwards, the separation of the groups (juveniles and adults) of males and females, in cases of overlap, each age category was divided into size classes $(2.5 \mathrm{~mm} \mathrm{CW})$ and the proportion of juveniles to adults in each size class of $\mathrm{CW}$ was calculated. The proportion of adults was fitted to a logistic equation $\left(y=a /\left(1+b e^{-c x}\right)\right)$. Subsequently, an interpolation was performed to determine the size at which $50 \%$ of the males and females were mature (adult) (CORGOS et al., 2006). Following the correct division of the groups, the transformed data $(\log 10)$ in each category were submitted to a covariance analysis (ANCOVA) to test the angular and linear coefficients between groups (juveniles and adults) ( $\alpha=0.05)$ (ZAR, 1996).

After that the separation of the groups of juveniles and adults (determinations of the morphological sexual maturity - CW50\%), a relative growth analysis was performed to observe the changes in growth patterns of some body parts in relation to carapace width using the allometric equation $y=a x b$ (HUXLEY 1950). The equation was linearized $(\log y=\log a+b \log x)$, where the carapace width (CW) was used as the independent variable $(x)$ and other related body size of crabs (the dependent variable, $y$ ). The " $b$ " in the equation is the allometric constant in which it is possible to determine the growth pattern of male and female crabs, expressing the analogy between two variables. $B>1$ comprises a positive allometric growth, $b=1$, isometric growth, and $b<1$, negative allometric growth. The meaning of " $b$ " related to the unit was verified by the Student's $t$-test $(\alpha=0.05)$. It was obtained potential and linear equations for the juveniles and adults studied in each group. To test intercept equality $(a)$ and the regression coefficients $(b)$, for both juveniles and adults, and also between lines a co-variance analysis (ANCOVA; $\alpha=0.05$ ) was performed (ZAR, 1996).

\section{RESULTS}

A total of 1,198 specimens of Uca maracoani were sampled in the Formoso River mangrove, i.e., 753 males (62.91\%) and 445 females (37.09\%). The minimum, mean ( \pm standard deviation), and maximum values of each body variable are showed in the Table 1 . The carapace width (CW) for males varied from 5.86 to $36.11 \mathrm{~mm}(22.9 \pm 6.6 \mathrm{~mm})$ and for females from 7.21 to $32.05 \mathrm{~mm}(20.19 \pm 5.24 \mathrm{~mm})$. The males showed a mean size of carapace width significantly larger than the females $(t=7.39)(p<0.05)$.

The relationship between body dimensions obtained for males and females in each life stage (juveniles and adult) and CW 50\% for each U. maracoani are shown in Table 2. The growth patterns for both sexes were significantly different for size classes, for juveniles and for adults (Figure 1). Intercepts and regression coefficients of all the allometric relationships were different between juveniles and adults for both sexes $(p<0.05)$ (Table 3$)$, thus indicating contrasting growth patterns.

Table 1: Results of biometric analyses (in $\mathrm{mm}$ ) obtained in the present study for males and females of Uca maracoani from the Formoso River, northeastern Brazil.

\begin{tabular}{ccccccc} 
& \multicolumn{3}{c}{ Males } & \multicolumn{2}{c}{ Females } \\
\cline { 2 - 6 } $\begin{array}{c}\text { Biometric } \\
\text { variables }\end{array}$ & Min. & Max. & Mean \pm Sd & Min. & Max. \\
nW & 5.86 & 36.11 & $22.90 \pm 6.60$ & 7.21 & 32.05 & $20.19 \pm 5.24$ \\
CL & 4.37 & 22.86 & $15.18 \pm 4.18$ & 4.97 & 21.99 & $13.92 \pm 3.64$ \\
AW & 1.56 & 9.43 & $5.90 \pm 1.63$ & 2.23 & 16.87
\end{tabular}




$\begin{array}{ccccccc}\mathrm{CPL} & 1.96 & 61.70 & 30.00 \pm 14.83 & 1.87 & 13.14 & 7.96 \pm 2.25 \\ \mathrm{CPH} & 1.12 & 20.11 & 11.39 \pm 4.68 & 0.76 & 3.54 & 2.20 \pm 0.54 \\ \mathrm{GL} & 1.78 & 14.49 & 8.95 \pm 2.61 & & & \end{array}$

$\mathrm{CW}=$ carapace width; $\mathrm{CL}=$ carapace length; $\mathrm{AW}=$ abdomen width; $\mathrm{CPL}=$ cheliped propodus length; $\mathrm{CPH}=\mathrm{cheliped}$ propodus height; $\mathrm{GL}=$ gonopods length; $\mathrm{Min}=$ minimum; $\mathrm{Max}=$ maximum; $\mathrm{Sd}=$ standard deviation.

Table 2: Results of Students " $t$ " test analyses for relative growth equations constants (" $a$ " and " $b$ ") for males and females of Uca maracoani from the Formoso River mangrove, northeastern Brazil.

\begin{tabular}{|c|c|c|c|c|c|c|c|}
\hline \multirow[t]{2}{*}{ Relationship } & \multirow[t]{2}{*}{ Sex phase } & \multirow[t]{2}{*}{$\mathbf{N}$} & \multirow[t]{2}{*}{ A } & \multirow[t]{2}{*}{ B } & \multicolumn{2}{|c|}{ Student's t-test } & \multirow[t]{2}{*}{ CW50\% } \\
\hline & & & & & t angle "b" & t linear "a" & \\
\hline \multirow[t]{4}{*}{ CL vs. CW } & $\mathrm{JM}$ & 179 & 0.7285 & 0.97 & 95.98* & $101.37^{*}$ & 18.1 \\
\hline & AM & 533 & 0.8972 & 0.90 & & & \\
\hline & $J F$ & 117 & 0.6906 & 0.99 & $174,16^{*}$ & $174,26^{*}$ & 17.0 \\
\hline & $\mathrm{AF}$ & 310 & 0.734 & 0.98 & & & \\
\hline \multirow[t]{4}{*}{ AW vs. CW } & $\mathrm{JM}$ & 184 & 0.278 & 0.98 & $594.70^{*}$ & $605.39 *$ & 18.4 \\
\hline & AM & 532 & 0.4114 & 0.85 & & & \\
\hline & $\mathrm{JF}$ & 103 & 0.1199 & 1.42 & $1159.40^{*}$ & $1121.02^{*}$ & 16.0 \\
\hline & $\mathrm{AF}$ & 341 & 0.2282 & 1.26 & & & \\
\hline \multirow[t]{4}{*}{ CPL vs. CW } & $\mathrm{JM}$ & 187 & 0.133 & 1.64 & $4344.52 *$ & $3606.26 *$ & 17.9 \\
\hline & AM & 566 & 0.059 & 1.96 & & & \\
\hline & $\mathrm{JF}$ & 119 & 0.1549 & 1.34 & $964.74^{*}$ & $851.74 *$ & 17.1 \\
\hline & $\mathrm{AF}$ & 308 & 0.3193 & 1.07 & & & \\
\hline \multirow[t]{4}{*}{$\mathrm{CPH}$ vs. CW } & JM & 189 & 0.0805 & 1.55 & $3550.63^{*}$ & $3567.43^{*}$ & 18.6 \\
\hline & AM & 526 & 0.141 & 1.39 & & & \\
\hline & $\mathrm{JF}$ & 115 & 0.1455 & 0.90 & 479.58* & $477.15^{*}$ & 16.9 \\
\hline & $\mathrm{AF}$ & 312 & 0.1864 & 0.82 & & & \\
\hline \multirow[t]{2}{*}{ GL vs. CW } & $\mathrm{JM}$ & 179 & 0.3682 & 1.01 & $400.02^{*}$ & $396.61^{*}$ & 17.9 \\
\hline & AM & 538 & 0.5628 & 0.88 & & & \\
\hline
\end{tabular}

$*=\mathrm{p}<0.05 ; \mathrm{CW}=$ carapace width; $\mathrm{CL}=$ carapace length; $\mathrm{CPL}=$ cheliped propodus length; $\mathrm{CPH}=$ major cheliped propodus height; $\mathrm{GL}=$ gonopod length; $\mathrm{Min}=\min ; \mathrm{Max}=$ maximum; $\mathrm{JM}=$ juvenile males; $\mathrm{AM}=$ Adult males; $\mathrm{JF}=$ juvenile females; $\mathrm{AF}=$ Adult females; $\mathrm{CW} 50 \%=$ carapace width in which $50 \%$ of males and females are morphologically mature.

The $U$. maracoani males showed negative allometry for both juveniles and adults in relation to $\mathrm{CL}$ vs. $\mathrm{CW}$ (for juvenile males $\mathrm{b}=0.97$, and for adult males $\mathrm{b}=0.90$, Figure $1 \mathrm{~A} ;$ Table $3 ; \mathrm{p}<0.05$ ). In females, this relationship was isometric for juvenile and adults (for juvenile females $b=0.99$, and for adult females $b$ $=0.98 ;$ Figure 1B; Table 3; $p>0.05$ ). The positive allometry was observed for juvenile and adult females (for juvenile $b=1.42$, and for adult $b=1.26$; Figure $1 C$, Table $3 p<0.05$ ), indicating a high growth rate in the juvenile phase for ratio AW vs. CW. However, juvenile males showed an isometry and adults a negative allometry for the relation AW vs. CW (for juveniles $b=0.98$, and for adults $b=0.85$; Figure 1D; Table 3; $p<$ 0.05).

In males, the CPL vs. CW ratio showed positive allometry, there is a remarkable increase in length soon after the changes of puberty, these results show an increase in the allometry coefficient for $U$. maracoani (for juveniles $b=1.64$, and for adults $b=1.96$; Figure 1E; Table $3 ; p<0.05$ ). A positive allometric growth was also observed in females for the CPL ratio vs. CW (juveniles and adults $b=1.34 \mathrm{~b}=1.07$; Figure 1F; Table 3; $\mathrm{p}<0.05)$. For the relationship $\mathrm{CPH}$ vs. $\mathrm{CW}$, positive allometry was observed in both phases, where the level of allometric chelipeds growth was sharper in the juvenile stage (juvenile $b=1.55$ and adult $\mathrm{b}=1.39$; Figure 1G; Table 3; $\mathrm{p}<0.05)$. However, the female juveniles showed an isometry pattern for this relationship $(b=0.90$; Figure $1 \mathrm{H} ; p>0.05)$ and adult females showed a negative allometric $(b=0.82$; Figure $1 \mathrm{H}$; Table 3; $\mathrm{p}<0.05)$.

Gonadal growth of males was different between the phases, but juveniles showed an isometric 
growth $(b=1.01$; Figure 1l; Table $3 ; p>0.05)$ and for adults a negative allometric growth $(b=0,88$; Figure 1l; Table 3; $p<0.05)$. The morphometric relationships that best evidenced the beginning of the morphological sexual maturity for U. maracoani were CPL vs. CW for males and AW vs. CW for females. Thus, the morphological sexual maturity of males was estimated at $15.8 \mathrm{~mm} \mathrm{CW}$ (50\% of males) (Figure 2), with the smallest mature male measuring $17.34 \mathrm{~mm}$, and the largest immature male $18.15 \mathrm{~mm} \mathrm{CL}$ (Figure 1E). Females reached morphological sexual maturity (50\%) at $13.8 \mathrm{~mm} \mathrm{CW}$ (Figure 2), with the smallest mature female at $15.43 \mathrm{~mm} \mathrm{CW}$ and the largest immature female at $16.32 \mathrm{~mm} \mathrm{CW}$ (Figure 1D).
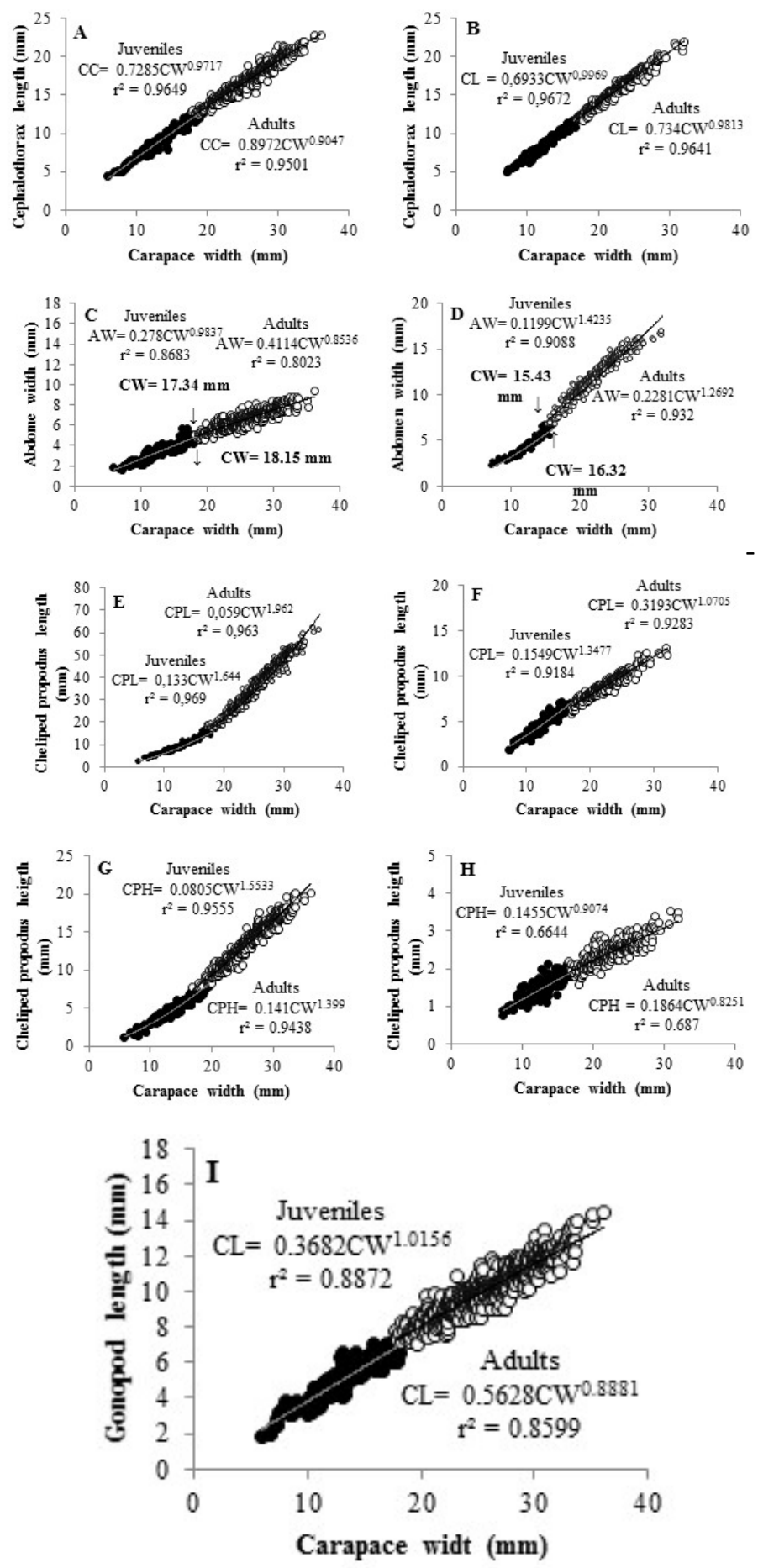

Figure 1. Allometric relationships for juveniles (full point) and adults (widely leaked point) of Uca maracoani, and fitted models for the following relationships: $\mathrm{CL}$ vs. CW males (A) and female (B); $A W$ vs. CW males (C) and female (D); CPL vs. CW of male (E) and female (F); CPH vs. CW for male (G) and female (H); GL vs. CW for males (I). 


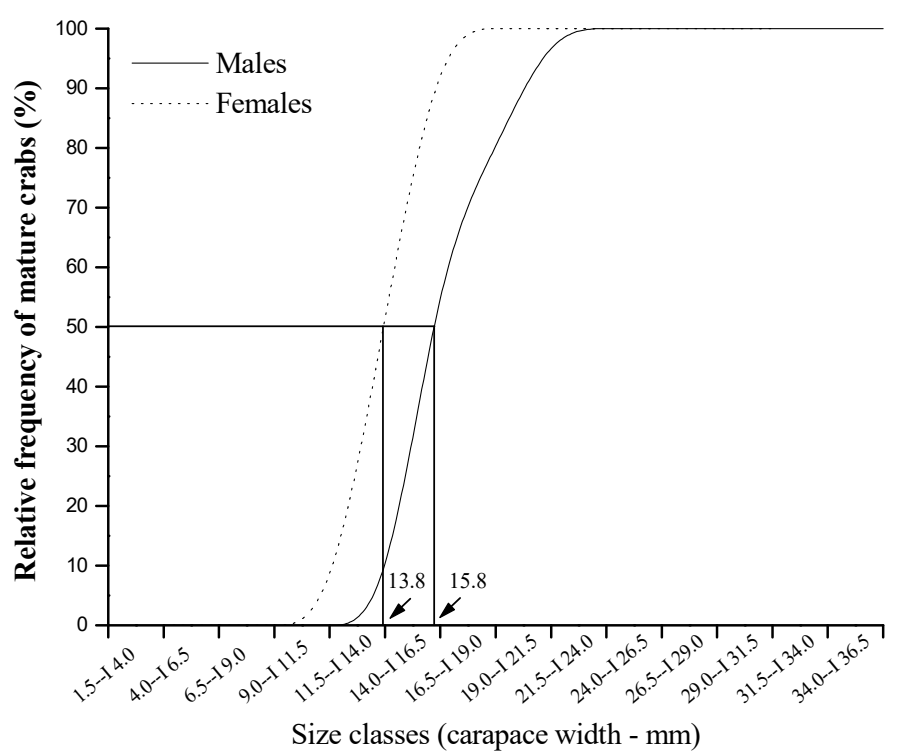

Figure 2: Morphological sexual maturity of males and females of Uca maracoani sampled in the Formoso River mangrove, state of Pernambuco, northeast Brazil. The arrows indicate the size at which $50 \%$ of the population is morphologically mature.

Table 3. Regression Analysis of morphometric data based on carapace width (CW) of Uca maracoani as independent variable in the Formoso River mangrove, northeast Brazil.

\begin{tabular}{|c|c|c|c|c|c|c|}
\hline Relationship & Sex & $\mathbf{N}$ & $\begin{array}{c}\text { Linear equation } \\
\text { Log } y=\log a+b \log x\end{array}$ & $r^{2}$ & Allometry & $t(b=1)$ \\
\hline \multirow[t]{4}{*}{ CL vs. CW } & $\mathrm{JM}$ & 179 & $\log C L=-0.13+0.97 \operatorname{LogCW}$ & 0.96 & - & $2.02 *$ \\
\hline & AM & 533 & $\log C L=-0.04+0.90 \mathrm{Log} C W$ & 0.95 & - & 10.59* \\
\hline & $\mathrm{JF}$ & 117 & $\log C L=-0.16+0.99 \operatorname{LogCW}$ & 0.96 & 0 & 0.09 \\
\hline & $\mathrm{AF}$ & 310 & $\log C L=-0.13+0.98 \mathrm{LogCW}$ & 0.96 & 0 & 1.73 \\
\hline \multirow[t]{4}{*}{ AW vs. CW } & JM & 184 & LogAW $=-0.55+0.98 \mathrm{LogCW}$ & 0.86 & 0 & 0.57 \\
\hline & AM & 532 & LogAW $=-0.38+0.85 \log C W$ & 0.80 & - & $7.95^{*}$ \\
\hline & $\mathrm{JF}$ & 103 & LogAW $=-0.92+1.42 \log C W$ & 0.90 & + & $-9.48 *$ \\
\hline & $\mathrm{AF}$ & 341 & LogAW $=-0.64+1.26 \log C W$ & 0.93 & + & $-14.43^{*}$ \\
\hline \multirow[t]{4}{*}{ CPL vs. CW } & JM & 187 & $\log C P L=-0.87+1.64 \operatorname{LogCW}$ & 0.96 & + & $-29.93 *$ \\
\hline & AM & 566 & $\log C P L=-1.22+1.96 \operatorname{LogCW}$ & 0.96 & + & $-60.18^{*}$ \\
\hline & $\mathrm{JF}$ & 119 & $\log C P L=-0.81+1.34 \operatorname{LogCW}$ & 0.91 & + & $-9.36^{*}$ \\
\hline & $\mathrm{AF}$ & 308 & $\log C P L=-0.49+1.07 \operatorname{LogCW}$ & 0.92 & + & $-4.14^{*}$ \\
\hline \multirow[t]{4}{*}{$\mathrm{CPH}$ vs. LC } & JM & 189 & $\log C P H=-1.09+1.55 \operatorname{LogCW}$ & 0.95 & + & $-22.57^{*}$ \\
\hline & AM & 526 & $\log C P H=-0.85+1.39 \log C W$ & 0.94 & + & $-26.76^{*}$ \\
\hline & JF & 115 & $\log \mathrm{CPH}=-0.83+0.90 \mathrm{LogCW}$ & 0.66 & 0 & 1.52 \\
\hline & $\mathrm{AF}$ & 312 & $\log C P H=-0.72+0.82 \log C W$ & 0.68 & - & $5.53^{*}$ \\
\hline \multirow[t]{2}{*}{ GL vs. CW } & $\mathrm{JM}$ & 179 & $\operatorname{LogGL}=-0.43+1.01 \mathrm{LogCW}$ & 0.88 & 0 & -0.57 \\
\hline & AM & 538 & $\operatorname{LogGL}=-0.24+0.88 \mathrm{LogCW}$ & 0.85 & - & $7.22 *$ \\
\hline
\end{tabular}

* = Student's t test $(\mathrm{p}<0.05) ; \mathrm{CW}=$ carapace width; $\mathrm{CL}=$ carapace length; $\mathrm{CPL}=$ cheliped propodus length; $\mathrm{CPH}=$ major cheliped propodus height; $\mathrm{GL}=$ gonopod length; $\mathrm{Min}=\min ; \mathrm{Max}=$ maximum; $\mathrm{JM}=$ juvenile males; $\mathrm{AM}=\mathrm{Adult}$ males; JF = juvenile females; $\mathrm{AF}=$ Adult females; $\mathrm{N}=$ number of subjects; $\mathrm{r}^{2}=$ coefficient of determination; $+=$ positive allometry; - = negative allometry; 0 = isometry.

The carapace width is usually considered to be the independent variable in morphometric studies of Brachyuran because it exhibits some morphological changes over the lifetime of the crab (CASTIGLIONI et al., 2004; CASTIGLIONI et al., 2011; ARAÚJO et al., 2012). Some dimensions can present different rates of growth, showing difference in the proportion with the size: the relative growth (HARTNOLL, 1978). The relative growth is closely related with gonadal maturation and changes in the life phases. Relationship between length and width are important tools to describe these changes (HARTNOLL, 1982).

Due to the observation of a negative allometric growth indicate that there is a higher growth of CW compared to $\mathrm{CL}$ in males of $U$. maracoani, which means a great lateral expansion of the carapace in 
comparison with its length. This result is very similar to that obtained by Negreiros-Fransozo et al. (2003) for the same species, M. rapax by Castiglioni \& Negreiros-Fransozo (2004) except for adult females which showed isometric growth for this relationship in both studies and by Castiglioni et al. (2011) for Ucides cordatus. The relationship CL vs. CW is not the most appropriate to express biological changes with reproductive meaning that occur in the life of crabs (SANTOS et al., 1995). Other parts of the body such as the abdomen and cheliped showed changes in the degree of allometry with puberty (CASTIGLIONI et al., 2004; CASTIGLIONI et al., 2011) and these are the most suitable for the study of relative growth and determination of morphological maturity.

In this study, the growth was allometric positive in the relationships $\mathrm{CPL}$ vs. $\mathrm{CW}$ and $\mathrm{CPH}$ vs. $\mathrm{CW}$ in males, showing a more evident cheliped growth (length) after the puberty molt, which probably is related to use of this appendage in reproductive behavior, particularly the cohorts that are visually predominant (HIROSE et al., 2007), considering that females are attracted by larger claws (CRANE, 1975). Masunari et al. (2005), Hirose \& Negreiros-Fransozo (2007) and Silva et al. (2016) also reported a positive allometry in chelipeds of $U$. maracoani for juveniles and adults. This cheliped growth pattern as observed in some species of fiddler crabs as L. thayeri (NEGREIROS-FRANSOZO et al., 2003), M. rapax (CASTIGLIONI et al., 2004), M. burgersi (BENETTI et al., 2004), M. mordax (MASUNARI et al., 2005), L. cumulanta (PRALON et al., 2008), L. thayeri (ARAÚJO et al., 2012) and U. uruguayensis (HIROSE et al., 2012).

In females, the abdomen growth showed high values of positive allometry, probably because this appendage provides a chamber where the egg mass is attached to the pleopods and protected during incubation time (HARTNOLL, 1982). This result was observed in adult females of the same species by Masunari et al. (2005), in juvenile females by Silva et al. (2016), and juvenile and adult females by Hirose \& Negreiros-Fransozo (2007). This positive allometric growth in cheliped as observed in some fiddler crab's species as L. thayeri (NEGREIROS-FRANSOZO et al., 2003), M. rapax (CASTIGLIONI et al., 2004), L. leptodactyla (CARDOSO et al., 2004), M. rapax (COSTA et al., 2008), L. cumulanta (PRALON et al., 2008) and L. thayeri (ARAÚJO et al., 2012).

It is well known that in Brachyura the most appropriate dimensions to determine the onset of morphological sexual maturity for males and females are the cheliped and abdomen, respectively (MASUNARI et al., 2003; CASTIGLIONI et al., 2004; CASTIGLIONI et al., 2011; ARAÚJO et al., 2012; HIROSE et al., 2013). Thus, the CPL and AW were the variables chosen in the present study to better illustrate the maturity in U. maraconi. In the present study, males reached maturity at larger CW than females. This fact was already observed in other populations of U. maracoani by Hirose et al. (2007) and Silva et al. (2016) and others fiddler crabs as M. burgersi by Benetti et al.(2004), M. rapax by Castiglioni et al. (2004, 2006), L. cumulanta by Pralon et al. (2008) and L. thayeri by Araújo et al. (2012). Males mature with larger sizes than females probably due to their greater investment in somatic growth, while females spend their energy in the reproductive process, saving energy for the development of the gonads and formation and maintenance off eggs (HARTNOLL, 2006; CASTIGLIONI et al., 2006; ARAÚJO et al., 2012).

In the present study, during the development of males and females, the analysis ascertained that 
50\% males and females are mature with 15.8 and $13.8 \mathrm{~mm}$, respectively. Masunari et al. (2005), Hirose et al.(2007) and Silva et al. (2016) (Table 4) found a different value of onset sexual maturity. These differences could be the result of ecological factors such as substratum, availability and quality of food, salinity, and exposure to tides (WENNER et al., 1974; GENONI, 1985; HINES, 1989; CASTIGLIONI et al., 2004; CASTIGLIONI et al., 2011). The differential growth patterns between juvenile and adult phases, as well as the onset sexual maturity seem to have relationship with ontogenetic changes, which is mainly related to behavioral or reproductive traits. The growth pattern observed in the female's abdomen is probably related to hatching eggs while overgrowth shown in male cheliped should be related to reproductive processes, as this appendix is used in court and in specific interactions with other males.

Table 4. Results of minimum, maximum, mean ( \pm standard deviation) and onset sexual maturity (CW50\%) in millimeters for populations of Uca maracoani. CW= carapace width.

\begin{tabular}{|c|c|c|c|c|c|c|}
\hline Population & Sex & $\begin{array}{l}\text { Minimum } \\
\text { size } \\
\text { (CW) }\end{array}$ & $\begin{array}{l}\text { Maximum } \\
\text { size } \\
\text { (CW) }\end{array}$ & $\begin{array}{l}\text { Mean size } \pm \\
\text { sd }\end{array}$ & CW50\% & Reference \\
\hline Guaratuba, PR (4836'W & Male & 3.36 & 34.15 & 21.53 & 17.85 & Masunari et al. (2005) \\
\hline and $25 \circ 52$ 'S) & Female & 3.18 & 29.2 & 19.3 & 11.75 & \\
\hline Paraty, RJ (2312'10"S & Male & 4.9 & 43.7 & $28.5 \pm 10.1$ & 21.2 & Hirose \& Negreiros- \\
\hline 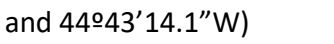 & Female & 5.1 & 38.7 & $24.9 \pm 7.9$ & 19.3 & Fransozo (2007) \\
\hline Baixa Grande, RN & Male & 12.4 & 38 & $27.1 \pm 5.47$ & 22.3 & Silva et al. (2016) \\
\hline 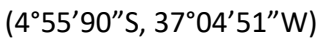 & Female & 15.7 & 36.7 & $23.4 \pm 4.2$ & 19.3 & \\
\hline Rio Formoso, PE & Male & 5.86 & 36.11 & $22.9 \pm 6.6$ & 15.8 & Present study \\
\hline $\begin{array}{l}\left(8^{\circ} 41^{\prime} 00.68 \text { "S and }\right. \\
\left.35^{\circ} 06^{\prime} 09.49^{\prime \prime} W\right)\end{array}$ & Female & 7.21 & 32.05 & $20.19 \pm 5.24$ & 13.8 & \\
\hline
\end{tabular}

Table 4 shows that there is no clear latitudinal pattern in the size of sexual maturity for Uca maracoani. However, there are still few studies regarding this species, and the sampling areas may vary regarding the anthropogenic impacts. For example, in a study performed by Araújo et al. (2012) with $L$. thayeri, in two mangrove areas of Pernambuco, males and females reached maturity at sizes larger in the most impacted area, probably because the individuals take advantage from the large availability of organic matter. Authors state that differences between sexes among populations may be related to the quantity of organic matter in the substrate, which may be a food resource for the crabs, and consequently, resulting in distinct growth rates (BENETTI et al., 2004; SILVA et al., 2016).

\section{REFERÊNCIAS}

ALMEIDA, A. O.; COELHO, P. A.; SANTOS, J. T. A.; FERRAZ, N. R.. Crustáceos decápodos estuarinos de Ilhéus, Bahia, Brasil. Biota Neotropica, v.6, n.2, p.24, 2006.

ARAÚJO, M. S. L. C.; COELHO, P. A.; CASTIGLIONI, D. S.. Relative growth and determination of morphological sexual maturity of the fiddler crab Uca thayeri Rathbun (Crustacea, Ocypodidae) in two mangrove areas from Brazilian tropical coast. Pan-American Journal of Aquatic Sciences, v.7, n.3, p.156-170, 2012.

AZEVEDO, D. S.; SILVA, J. V. C. L.; CASTIGLIONI, D. S.. Population biology of Uca maracoani in a tropical mangrove. Thalassas, v.33, n.1, p.1-13, 2017.

BENETTI, A. S.; NEGREIROS-FRANSOZO, M. L.. Relative growth of Uca burgersi (Crustacea, Ocypodidae) from two mangroves in the southeastern Brazilian coast. Iheringia, Série Zoologia, v.94, n.1, p.67-72, 2004.

BEZERRA, L. E. A.; DIAS, C. B.; SANTANA, G. X.; MATTHEWSCASCON, H.. Spatial distribution of fiddler crabs (genus Uca) in a tropical mangrove of northeast Brazil. Scientia Marina, v.70, n.4, p.759-766, 2006.

CARDOSO, F. C. R.; NEGREIROS-FRANSOZO, M. L.. A comparison of the allometric growth in Uca leptodactyla (Crustacea: Brachyura: Ocypodidae) from two subtropical estuaries. Journal of Marine Biology Association of United Kingdom, v.84, p.733-735, 2004.

CASTIGLIONI, D. S.; COELHO, P. A.. Determinação da maturidade sexual de Ucides cordatus (Crustacea, Brachyura, Ucididae) em duas áreas de manguezal do litoral 
sul de Pernambuco, Brasil. Iheringia Série Zoologia, v.101, n.1-2, p.138-144, 2011.

CASTIGLIONI, D. S.; NEGREIROS FRANSOZO, M. L.. Comparative analysis of the relative growth of Uca rapax (Smith, 1870) (Crustacea, Ocypodidae) from two mangroves in São Paulo, Brazil. Revista Brasileira Zoologia, v.21, n.1, p.137-144, 2004.

CASTIGLIONI, D. S.; SILVA, J. V. C.; AZEVEDO, D. S.. Relative growth and its use to determine the morphological sexual maturity of Ucides cordatus (Linnaeus, 1763) (Decapoda, Brachyura, Ucididae) from two mangrove areas on the Northeastern Brazilian coast. Crustaceana, v.84, n.10, p.1221-1241, 2011.

CASTIGLIONI, D. S.; ALMEIDA, A. O.; BEZERRA, L. E. A.. More common than reported: range extension, size-frequency and sex-ratio of Uca (Minuca) victoriana (Crustacea: Ocypodidae) in tropical mangroves, Brazil. Marine Biodiversity Records, v.3, p.1-8, 2010.

CASTIGLIONI, D. S.; NEGREIROS-FRANSOZO, M. L.; MORTARI, R. C.. Biologia populacional do caranguejo violinista Uca rapax (Smith, 1870) (Crustacea, Ocypodoidea), proveniente de uma área de manguezal degradado em Paraty, RJ, Brasil. Atlântica, v.28, n.2, p.73-86, 2006.

COLPO, K. D.; NEGREIROS-FRANSOZO, M. L.. Comparison of the population structure of the fiddler crab Uca vocator (Herbst, 1804) from three subtropical mangrove forests. Scientia Marina, v.68, n.1, p.139-146, 2004.

CORGOS, A.; FREIRE, J.. Morphometric and gonad maturity in the spider crab Maja brachydactyla: a comparison of methods for estimating size at maturity in species with determined growth. ICES Journal of Marine Science, v.63, p.851-859, 2006.

COSTA, T.; SOARES-GOMES, A.. Relative growth of the fiddler crab Uca rapax (smith) (Crustacea: Decapoda: Ocypodidae) in a tropical lagoon (Itaipu), Southeast Brazil. Pan-American Journal of Aquatic Sciences, v.3, n.2, p.94100, 2008.

COSTA, T.; SOARES-GOMES, A.. Population and structure biology of Uca rapax (Decapoda: Ocypodidae) in a tropical Coastal Lagoon (Itaipu), Southeast Brazil. Zoologia, v.26, n.4, p.647-657, 2009.

CPRH. Companhia Pernambucana de Recursos Hídricos. Diagnóstico socioambiental APA de Guadalupe. Recife, 1998.

CRANE, J.. Ocypodidae: genus Uca. New Jersey: Princepton University Press, 1975.

DALABONA, G; SILVA, J. L.; PINHEIRO, M. A. A.. Size at morphological maturity of Ucides cordatus (Linnaeus, 1763) (Brachyura, Ocypodidae) in the Laranjeiras Bay, southern Brazil. Brazilian Journal of Biology and Technology, v.48, n.1, p.139-145, 2005.

DI BENEDETTO, M; MASUNARI, S.. Estrutura populacional de Uca maracoani (Decapoda, Brachyura, Ocypodidae) no Baixio Mirim, Baía de Guaratuba, Paraná. Iheringia, Serie Zoologia, v.99, n.4, p.381-389, 2009.

FLORES, A. V.; SARAIVA, J.; PAULA, J.. Sexual maturity, reproductive cycles, and juvenile recruitment of Perisesarma guttatum (Brachyura, Sesarmidae) at Ponta Rasa mangrove swamp, Inhaca Island, Mozambique. Journal of Crustacean Biology, v.22, n.1, p.142-156, 2002.

GARCIA-DÁVILA, C. R.; MAGALHÃES, C.; GUERRERO, J. C. H. Morphometric variability in populations of Palaemonetes spp. (Crustacea, Decapoda, Palaemonidae) from the Peruvian and Brazilian Amazon Basin. Iheringia, Série Zoologia, v.95, n.3, p.327-334, 2005.

GENONI, G. P.. Food limitation in salt marsh fiddler crabs Uca rapax (Smith) (Decapoda, Ocypodidae). Journal of Experimental Marine Biology and Ecology, v.87, p.97-110, 1985.

GONZÁLEZ-GURRIARÁN, E.; FREIRE, J.. Sexual maturity in the velvet swimming crab Necora puber (Brachyura, Portunidae): morphometric and reproductive analyses. Journal of Marine Science, v.51, n.2, p.133-145, 1994.

GREGATI, R. A.; NEGREIROS-FRANSOZO, M. L.. Relative growth and morphological sexual maturity of Chasmagnathus granulatus (Crustacea, Varunidae) from a mangrove area in southeastern Brazilian coast. Iheringia, Série Zoologia, v.97, n.3, p.268-272, 2007.

HAEFNER, P. A. JR.. Morphometry and size at maturity of Callinectes ornatus (Brachyura, Portunidae) in Bermuda. Bulletin of Marine Science, v.46, n.2, p.264-286, 1990.

HARTNOLL, R. G.. Variation in growth pattern between some secondary sexual characters in crabs (Decapoda, Brachyura). Crustaceana, v.27, n.2, p.131-156, 1974.

HARTNOLL, R. G.. The determination of relative growth in Crustacea. Crustaceana, v.34, n.3, p.281-293, 1978.

HARTNOLL, R. G.. Growth, sexual maturity and reproductive output. In: WENNER, A. M.. Factors in adult growth. 1985, p. 15-17.

HARTNOLL, R. G.; GROWTH. In: BLISS D. E.. The Biology of Crustacea: embriology, morphology and genetics. Academic Press, v.2, p.11-196, 1982.

HARTNOLL, R. G.. Reproductive investment in Brachyura. Hydrobiologia, v.557, p.31-40, 2006.

HINES, A. H.. Geographic variation in size at maturity in Brachyuran crabs. Bulletin of Marine Science, v.45, p.356368, 1989.

HIROSE, G. L.; NEGREIROS-FRANSOZO, M. L.. Growth phases and differential growth between sexes of Uca maracoani Latreille, 1802-1803 (Crustacea, Brachyura, Ocypodidae). Gulf and Caribbean Research, v.19, p.43-50, 2007.

HIROSE, G. L.; NEGREIROS-FRANSOZO, M. L.. Population biology of Uca maracoani Latreille 1802-1803 (Crustacea, Brachyura, Ocypodidae) on the southeastern coast of Brazil. Pan-American Journal of Aquatic Sciences, v.3, n.3, p.373383, 2008.

HIROSE, G. L.; NEGREIROS-FRANSOZO, M. L.. Comparison of body size, relative growth and size at onset sexual maturity of Uca uruguayensis (Crustacea: Decapoda: Ocypodidae) from different latitudes in the south-western Atlantic. Journal of the Marine Biological Association of the United 
Kingdom, v.93, n.3, p.781-788, 2012.

HUBER, M. E.. Allometric growth of the carapace in Trapezia (Brachyura, Xanthidae). Journal of Crustacean Biology, v.5, n.1, p.79-83, 1985.

HUXLEY, J. S.. Relative growth and form transformation. Proceedings of Royal Society of London, v.137, p.465-469. 1950.

KOCH, V.; WOLFF, M.; DIELE, K.. Comparative population dynamics of four fiddler crabs (Ocypodidae, genus Uca) from a North Brazilian mangrove ecosystem. Marine Ecology and Progress Series, v.291, p.177-188, 2005.

MASUNARI, S.; DISSENHA, N.. Alometria no crescimento de Uca mordax (Smith) (Crustacea, Decapoda, Ocypodidae) na Baía de Guaratuba, Paraná, Brasil. Revista Brasileira de Zoologia, v.22, n.4, p.984-990, 2005.

MASUNARI. S.; SWIECH-AYOUB, B. P.. Crescimento relativo em Uca leptodactyla Rathbun (Crustacea, Decapoda, Ocypodidae). Revista Brasileira de Zoologia, v.20, n.3, p.487-491, 2003.

MASUNARI, S.; DISSENHA, N.; FALCÃO, R. C.. Crescimento relativo e destreza dos quelípodos de Uca maracoani (Lareille) (Crustacea, Decapoda, Ocypodidae) no Baixo Mirim, Baía de Guaratuba, Paraná, Brasil. Revista Brasileira de Zoologia, v.22, n.4, p. 974-983, 2005.

MELO, G. A. S.. Manual de identificação dos Brachyura (caranguejos, siris) do litoral brasileiro. São Paulo: Plêiade, 1996.

NEGREIROS-FRANSOZO, M. L.; COLPO, K. D.; COSTA, T. M. Allometric growth in the fiddler crab Uca thayeri (Brachyura, Ocypodidae) from a subtropical mangrove. Journal of Crustacean Biology, v.23, n.2, p.273-279, 2003.

PINHEIRO, M. A. A.; FRANSOZO, A.. Sexual maturity of speckled swimming crab Arenaeus cribrarius (Lamarck, 1818) (Decapoda, Brachyura, Portunidae), in the Ubatuba littoral, São Paulo state, Brazil. Crustaceana, v.71, n.6, p.1547, 1998.
PRALON, B. G. N.; NEGREIROS-FRANSOZO, M. L.. Relative growth and morphological sexual maturity of Uca cumulanta (Crustacea: Decapoda: Ocypodidae) from a tropical Brazilian mangrove population. Journal of the Marine Biological, v.88, n.3, p.569-574, 2008.

SAMPEDRO, M. P.; GONZÁLEZ-GURRIARÁN, E.; FREIRE, J.; MUIÑO, R.. Morphometry and sexual maturity in the spider crab Maja squinado (Decapoda: Majidae) in Galicia, Spain. Journal of Crustacean Biology, v.19, n.3, p.578-592, 1999.

SANTOS, S.; NEGREIROS-FRANSOZO, M. L.; FRANSOZO, A.. Morphometric relationships and maturation in Portunus spinimanus Latreille, 1819 (Crustacea, Brachyura, Portunidae). Revista Brasileira de Biologia, v.55, n.4, p.545553, 1995.

SHIH, H. T.; NG, P. K. L.; DAVIE, P. J. F.; SCHUBART, C. D.; TURKAY, M.; NADERLOO, R.; JONES, D.; LIU, M. Y.. Systematics of the family Ocypodidae Rafinesque, 1815 (Crustacea: Brachyura), based on phylogenetic relationships, with a reorganization of subfamily rankings and a review of the taxonomic status of Uca Leach, 1814, sensu lato and its subgenera. Raffles Bulletin of Zoology, v.64, p.139-175, 2016.

SILVA, F. M. R. O.; RIBEIRO, F. B.; BEZERRA, L. E. A. Population biology and morphometric sexual maturity of the fiddler crab Uca (Uca) maracoani (Latreille, 1802) (Crustacea: Decapoda: Ocypodidae) in a semi-arid tropical estuary of northeastern Brazil. Latin American Journal of Aquatic Research, v.44, n.4, p.671-682, 2016.

THURMAN, L. C.; FARIA, S. C.; MCNAMARA, J. C.. The distribution of fiddler crabs (Uca) along the coast of Brazil: implications for biogeography of the western Atlantic Ocean. Marine Biodiversity records, v.6, n.1, p.1-21, 2013.

WENNER, A. M.; FUSARO, C.; OATEN, A. . Size at onset of sexual maturity and growth rate in crustacean populations. Canadian Journal of Zoology, v.52, n.9, p.1095-1106, 1974.

ZAR, J. H.. Biostatistical analysis. Prentice-Hall, Upper Saddle River, p.662, 1996

A CBPC - Companhia Brasileira de Produção Científica (CNPJ: 11.221.422/0001-03) detém os direitos materiais desta publicação. Os direitos referem-se à publicação do trabalho em qualquer parte do mundo, incluindo os direitos às renovações, expansões e disseminações da contribuiç̃o, bem como outros direitos subsidiários. Todos os trabalhos publicados eletronicamente poderão posteriormente ser publicados em coletâneas impressas sob coordenação da Sustenere Publishing, da Companhia Brasileira de Produção Científica e seus parceiros autorizados. Os (as) autores (as) preservam os direitos autorais, mas não têm permissão par a publiçção da contribuição em outro meio, impresso ou digital, em português ou em tradução. 